\title{
Status, distribution and local initiatives taken to conserve river dolphin, Platanista gangetica at Prakashpur-Koshi Barrage section of Koshi River
}

\author{
M. Aryal ${ }^{1 *}$, T.K. Shrestha ${ }^{2}$, R.P. Sapkota ${ }^{1}$ \\ ${ }^{1}$ Central Department of Environmental Science, Tribhuvan University, Kathmandu, Nepal \\ ${ }^{2}$ Central Department of Zoology, Tribhuvan University, Kathmandu, Nepal
}

\begin{abstract}
The Gangetic River Dolphin Platanista gangetica is an endangered species and this species has also been included under Appendix I of CITES. This study was based on direct count method by raft survey and multiplatform survey. In addition, questionnaire survey was also conducted with locals and fishermen of the study area to know their perceptions on dolphin. The water quality of the sites, where dolphin were seen, was analyzed using standard methods. Two dolphins were observed in the upper section of the Koshi Barrage and this is a very low number that could extinct in very future if no conservation measures are taken. Also, a rare sighting of the species has been reported by locals near irrigation canals and small tributaries of the Koshi River. Survey carried out below the Koshi Barrage revealed only four dolphins. According to local people, 10 to 15 dolphins used to appear in this section but because of change in the course by Koshi River due to the outburst of Koshi Dam, there was a low water level to support the dolphin habitat, so they might have migrated to the Ganges in India. The water quality of Koshi at the site of dolphins occurrence was determined to be normal. Accidental trapping and killing of dolphin with the use of fishing nets are identified as major threat. Various human activities like fishing, washing, transporting forest products, establishment of the ferry, construction of irrigation canals, high dams etc. are some of the major threats to dolphins. Low level of awareness among people was noticed for the conservation of dolphins.
\end{abstract}

Key words: Conservation, Endangered species, Multiplatform survey, River Dolphin

\section{Introduction}

Dolphins have been known to fascinate human civilization for several millennia. Human-Dolphin relations have been recorded with sea faring communities as far as with ancient Hindu and Greek mythology. The four genera of world's river dolphins (Inia, Pontoporia, Lipotes and Platanista) are among the least known and most endangered of all Cetaceans. The Ganges river dolphins are facing population threats due to incidental and killings as well as habitat degradation due to siltation, pollution and water development projects. The Ganges river dolphins are usually solitary but are also occasionally observed in group of 2-3 individuals often inhabiting places below the sandbars and tributary junctions and areas where eddy counter current system is developed due to convergence of stream with main stream flow (Sinha et al., 2004). Shrestha studied status and ecology
\end{abstract}

${ }^{\star}$ Corresponding author, email address: mabhaiaryal@gmail.com of the Gangetic dolphin in Nepal for the first time and reported declining population trend (Shrestha, 1986a,b).

The Gangetic dolphin (Platanista gangetica gangetica) is found in the Ganges-Brahmaputra-Meghna and Karnapuli River systems of India, Nepal and Bangladesh. In the 19th century, these dolphins were abundant in the entire distributional range, though no actual population data are available. However, due to various pressures, these distributional range and abundance of this species have been sharply declined. The IUCN revised its 'threatened' status from 'vulnerable' to 'endangered' because of large population decline of the species (IUCN, 1996) and because the factors causing decline (entanglement in fishing gears, diversion of water, pollution and fragmentation of habitats) are still present, not fully understood and are not reversible (Wakid, 
2005). Although its status remains endangered, it has been classified as 'Not Evaluated' since there has been no combined assessment of the species (IUCN, 2004).

The general objective of the study is to identify the existing information on the Gangetic dolphin in the Koshi River. The specific objectives of the study are (1) to assess the status, distribution and threats to the Gangetic River Dolphin Platanista gangetica in the Prakashpur-Koshi Barrage Section of the Koshi River, (2) to analyze the physicochemical parameters of river water at the dolphin habitat, (3) to determine the existing conservation measures practiced by different stakeholders.

\section{Materials and Methods \\ Study area}

Koshi Tappu Wildlife Reserve (KTWR) is a freshwater, natural and permanent river system located on the flood plains of Sapta Koshi River. It is a major river system in Nepal that originates in the Central Himalayas. Koshi Tappu is a rectangular shaped reserve and was formed by the Koshi Barrage near Nepal-India border on the East-West Mahendra National Highway. It was designated as Ramsar site in $17-$ 12-1987. It has Coordinates: $26^{\circ} 39^{\prime} 00^{\prime \prime} \mathrm{N} 86^{\circ} 59^{\prime} 00^{\prime \prime} \mathrm{E}$ and covers an area of 17,500 ha with length $24 \mathrm{~km}^{2}$ and elevation of $75 \mathrm{~m}-81 \mathrm{~m}$.

The intensive study area was from Prakaspur VDC, the Reserve boarder to Koshi Barrage of Sunsari district about $40 \mathrm{~km}$ length. The water level in study area was relatively higher than the adjoining tributary rivers.

\section{Data collection and analysis}

The study was concentrated in Koshi Tappu Wildlife Reserve (KTWR) from Prakashpur, Reserve border to Koshi Barrage

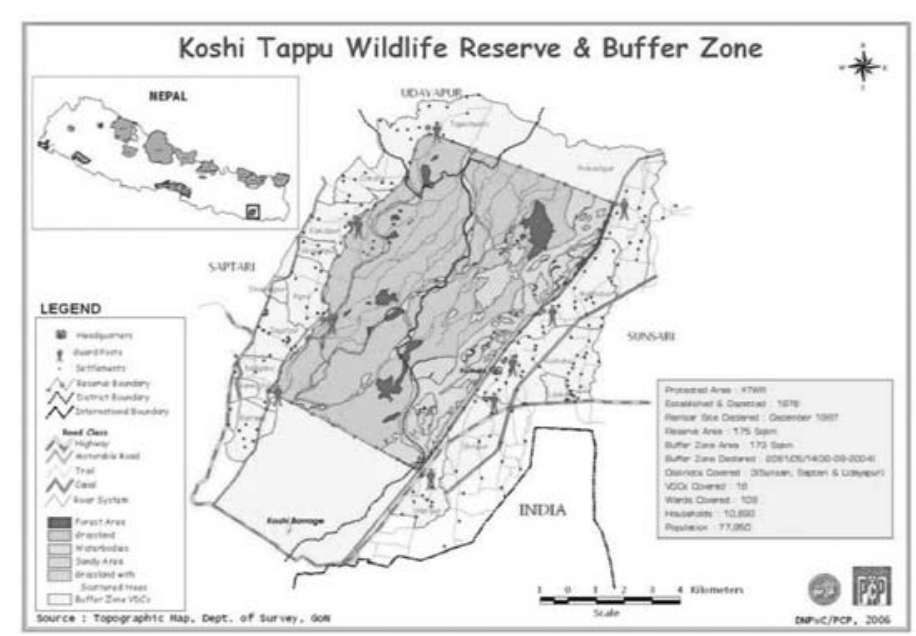

Fig. 1 Location of the study area from 13 April, 2009 to 6 May, 2009. Detail survey was carried out with the help of reserves officials, local people and fishermen to locate the potential sites of the river. These sites were visited to record dolphins. A direct count measures was applied to estimate the population status through Raft Survey and Multiplatform Count Methods (Shrestha, 1989). During Raft Survey, Two persons (left and right side of the raft) were posted to spot the dolphins. Counting of surfacing dolphins was done from the wooden raft. Each time, at least 30 minutes was spent where dolphins were sighted. Search effort was made for about 30 minutes on the potential dolphin habitats where the convergent streams form the eddy counter current system. Ten observations of the time of dolphin surfacing and coincide of their surfacing were also noted for confirmation. Apart from this, several isolated visits to the dolphin habitat was done to get various information regarding dolphin. GPS points were noted where dolphin were sighted. During Multiplatform Count, the bank of the river was used as the platform for sighting the surfacing of dolphins. Different persons were posted in different places (Coffer Dam No. 2 and Koshi Barrage) for counting the dolphins for three days (3, 4 and 5 May 2009) and between fixed time periods (7-10 AM/1May, 1-3 PM/2 May, 5-7 PM/3 May) .

Questionnaire survey, a total of 127 households, was conducted to get information about the abundance of dolphin and their habitats in KTWR and the population trend of dolphin over the years. Qualitative information on the occurrence and distribution of dolphin was obtained from KTWR staff and Buffer Zone Committees. The major focus of this survey was fishermen living along the Koshi River for their livelihood since decades.

A total of 20 water samples, 10 samples from each site (Coffer Dam and Koshi Barrage) were collected. The water samples were taken at $6.30 \mathrm{pm}$ in 2nd May 2009 at Coffer Dam and 5.30 pm in 3rd May 2009 at Koshi Barrage at the place of dolphins found. The water quality was analyzed at the site and at laboratory of Central Department of Environmental Science, Tribhuvan University, Kathmandu, Nepal, following the standard methods (APHA, AWWA, WEF, 1998; Trivedy \& Goel, 1986). The data obtained were analyzed by using Microsoft Excel 2007 and an average data at each site has been presented. 


\section{Results}

\section{Status and present distribution of river dolphins}

During this study period, two raft surveys were conducted, first on 18th and 19th April from Prakashpur to Coffer Dam and second on 26th and 27th April from Coffer Dam to Koshi Barrage. It was found a total count of 6 river dolphins. Two river dolphins were sighted in the river section upstream of the Koshi Barrage at Madhuban V.D.C. ward No. 9, $\left(26^{\circ} 38^{\prime}\right.$ 503 ”N, and $87^{\circ} 01^{\prime} 723$ "E) at time 5:45 PM on April 18, where a Coffer Dam was constructed (eastern face $26^{\circ} 38^{\prime}$ 343 'N and $87^{\circ} 01^{\prime} 392$ 'E, mid face $26^{\circ} 38^{\prime} 345^{\prime \prime} \mathrm{N}$ and $87^{\circ}$ $01^{\prime} 397^{\prime \prime} \mathrm{E}$ and western face $26^{\circ} 38^{\prime} 340^{\prime \prime} \mathrm{N}$ and $87^{\circ} 01^{\prime} 388^{\prime \prime} \mathrm{E}$ )

for the maintenance of the damaged Koshi dam at West Kushaha near KTWR office. Similarly, survey carried out at Koshi Barrage indicated four dolphins near the downstream eastern section of Koshi barrage at $26^{\circ} 38^{\prime} 503^{\prime \prime} \mathrm{N}$ and $87^{\circ}$ 01' 723'E at 5:09 PM on April 26.

Multiplatform counts were conducted on 1, 2 and 3 May 2009, at two different sites, Coffer Dam and Lower Part of Koshi Barrage, where dolphins were sighted during raft surveys. Following results have been found during this study:

Table 1 The number of the Gangetic River Dolphin between Prakashpur (Border of KTWR) and Koshi Barrage

\begin{tabular}{|c|c|c|c|c|}
\hline Survey Section & No. of Dolphins & Time/ Date of Sighting & GPS Reading & Remarks \\
\hline Prakashpur & 0 & $\begin{array}{c}\text { 10:35-11:10AM/ } \\
\text { April 18, 2009 }\end{array}$ & $\begin{array}{l}26^{\circ} 38^{\prime} 398^{\prime \prime} \mathrm{N} \\
87^{\circ} 02^{\prime} 018^{\prime \prime} \mathrm{E}\end{array}$ & $\begin{array}{l}\text { Multi channels with high } \\
\text { current of water and high } \\
\text { human disturbances }\end{array}$ \\
\hline $\begin{array}{c}\text { Madhuban, } 9 \\
\text { (Coffer Dam No.2) }\end{array}$ & 2 & $\begin{array}{c}\text { 05:45-06:20 PM/ } \\
\text { April 18, } 2009\end{array}$ & $\begin{array}{l}26^{\circ} 38^{\prime} 396 " \mathrm{~N} \\
87^{\circ} 02^{\prime} 0199^{\prime \prime} \mathrm{E}\end{array}$ & $\begin{array}{c}\text { Deep and water with feeble } \\
\text { current and high human } \\
\text { disturbances }\end{array}$ \\
\hline $\begin{array}{l}\text { Upper part of } \\
\text { Koshi Barrage }\end{array}$ & 0 & $\begin{array}{c}\text { 04:35-05:10 PM/ } \\
\text { April 26, } 2009\end{array}$ & $\begin{array}{l}26^{\circ} 38^{\prime} 496 ” \mathrm{~N} \\
87^{\circ} 01^{\prime} 720^{\prime \prime} \mathrm{E}\end{array}$ & $\begin{array}{c}\text { Shallow and low amount of } \\
\text { water due to all open gates } \\
\text { of Koshi Barrage, rapidly } \\
\text { flowing water with low } \\
\text { human disturbances }\end{array}$ \\
\hline $\begin{array}{l}\text { Lower Part of } \\
\text { Koshi Barrage } \\
\text { (Eastern Section) }\end{array}$ & 4 & $\begin{array}{l}\text { 05:20-06:00 PM/ } \\
\text { April 26, } 2009\end{array}$ & $\begin{array}{l}26^{\circ} 38 ' 503 ” \mathrm{~N} \\
87^{\circ} 01 ' 723 ” \mathrm{E}\end{array}$ & $\begin{array}{c}\text { Deep water with high } \\
\text { current and high human } \\
\text { disturbances. }\end{array}$ \\
\hline
\end{tabular}

Table 2 Dolphins sighted during Multiplatform count

\begin{tabular}{|c|c|c|c|c|c|}
\hline S.N. & Sites & $\begin{array}{c}\text { Time/Date of } \\
\text { Dolphin sighted }\end{array}$ & $\begin{array}{l}\text { No. of } \\
\text { Dolphins }\end{array}$ & GPS Reading & Remarks \\
\hline 1 & Madhuban, 9 (Coffer Dam No. 2) & $\begin{array}{l}\text { 7-10 AM/1May } \\
\text { 1-3 PM/2 May } \\
\text { 5-7 PM/3 May }\end{array}$ & $\begin{array}{l}2 \\
2 \\
2\end{array}$ & $\begin{array}{l}26^{\circ} 38^{\prime} 396 \text { ”N } \\
87^{\circ} 02^{\prime} 019 \text { ”E }\end{array}$ & $\begin{array}{c}\text { Morning } \\
\text { Afternoon } \\
\text { Evening }\end{array}$ \\
\hline 2 & Lower Part of Koshi Barrage & $\begin{array}{l}\text { 7-10 AM/1 May } \\
\text { 1-3 PM/2 May } \\
\text { 5-7 PM/3 May }\end{array}$ & $\begin{array}{l}4 \\
4 \\
4\end{array}$ & $\begin{array}{l}26^{\circ} 38^{\prime} 503 \text { ”N } \\
87^{\circ} 01^{\prime} 723 \text { ”E }\end{array}$ & $\begin{array}{l}\text { Morning } \\
\text { Afternoon } \\
\text { Evening }\end{array}$ \\
\hline
\end{tabular}


Water quality analysis at the site of dolphin seen

Table 3 shows the physicochemical parameters (average) of the water at Coffer Dam and Koshi Barrage where dolphins were seen.
Change on population of dolphin in the Koshi river

Of the total respondents, $79.31 \%$ said that the population of dolphin in Koshi is changing. Of the total respondents reporting the change in the population of dolphin in Koshi, $51.71 \%$ report for the decrease in number and $27.58 \%$ for the increase in the number of dolphins (Fig. 2, 3).

Table 3 Physicochemical parameters of Koshi water at the site of Dolphin seen

\begin{tabular}{clcc}
\hline S.N. & \multicolumn{1}{c}{ Parameters/ Units } & Coffer Dam & Koshi Barrage \\
\hline 1. & Air Temperature $\left({ }^{\circ} \mathrm{C}\right)$ & 29.0 & 30.0 \\
2. & Water Temperature $\left({ }^{\circ} \mathrm{C}\right)$ & 26.0 & 29.0 \\
3. & pH & 6.0 & 6.0 \\
4. & Conductivity (Micro Simons/cm) & 94.0 & 110.0 \\
5. & DO $(\mathrm{mg} / \mathrm{L})$ & 8.10 & 8.51 \\
6. & Free $\mathrm{CO}_{2}(\mathrm{mg} / \mathrm{L})$ & 1.76 & 0.88 \\
7. & Alkalinity $(\mathrm{as} \mathrm{CaCO} 3)(\mathrm{mg} / \mathrm{L})$ & 8.0 & 8.0 \\
8. & Chloride $(\mathrm{mg} / \mathrm{L})$ & 117.04 & 119.88 \\
9. & Total Hardness $($ as $\mathrm{CaCO} 3)(\mathrm{mg} / \mathrm{L})$ & 0.44 & 0.36 \\
10. & Calcium Hardness $(\mathrm{mg} / \mathrm{L})$ & 0.28 & 0.24 \\
11. & Magnesium Hardness $(\mathrm{mg} / \mathrm{L})$ & 0.16 & 0.12 \\
12. & Phosphate as Phosphorous $(\mathrm{mg} / \mathrm{L})$ & 0.62 & 0.59 \\
13. & Iron (mg/L) & 0.15 & 0.13 \\
14. & Ammonia $(\mathrm{mg} / \mathrm{L})$ & 0.018 & 0.037 \\
15. & Nitrate as Nitrogen $(\mathrm{mg} / \mathrm{L})$ & 0.33 & 0.33 \\
\hline
\end{tabular}

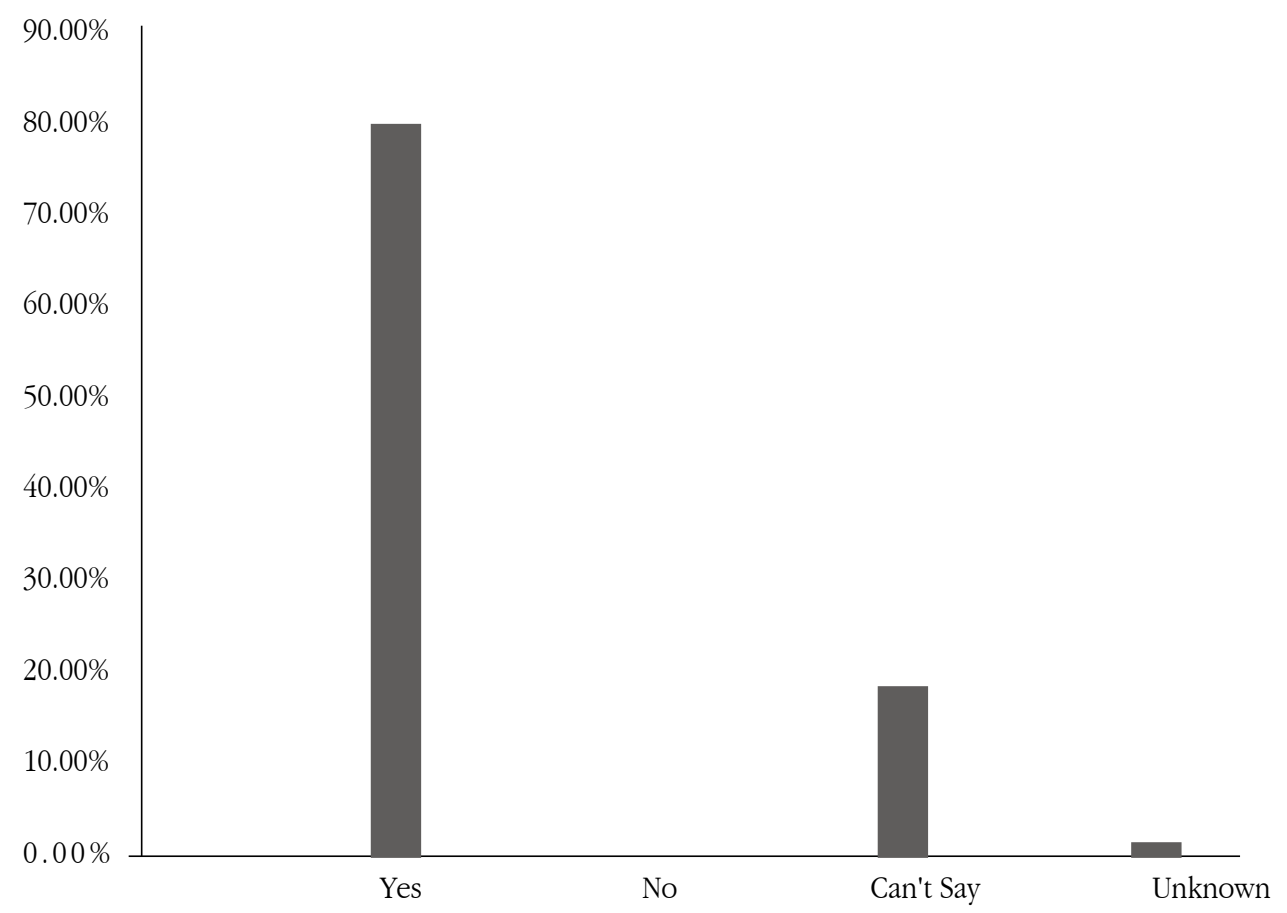

Fig. 2 People's response to the change in the population of Dolphin 


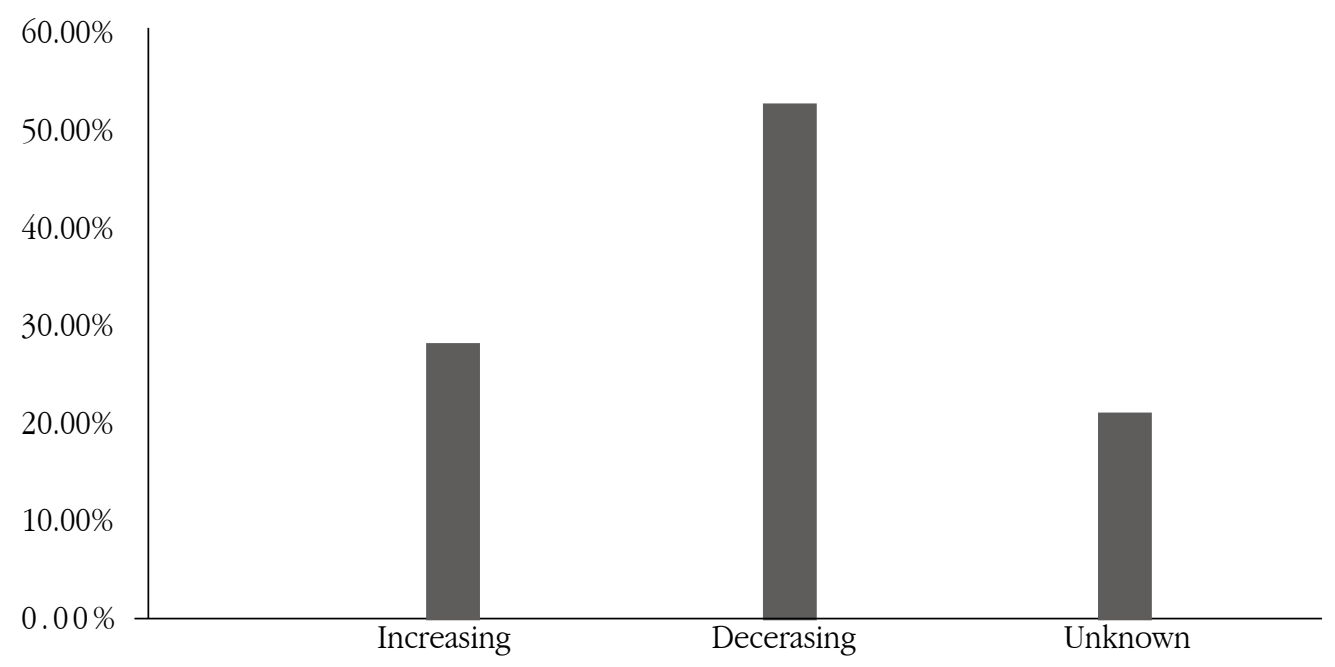

Fig. 3 People's perception on change in Dolphin population

\section{Number of dolphins in the Koshi river}

Among the respondents, $44.82 \%$ reported that the number of dolphin in the Koshi River is between 5 to10 while 37.93\% of the respondents replied that it is less than five in number (Fig. 4).

\section{Threats to dolphin population}

Among the respondents, $82.75 \%$ clamed that the main cause of the change in the number of the dolphin is flood. The other threats that decrease the number of the dolphins in the Koshi River are over fishing, poaching and development of infrastructures (Fig. 5).

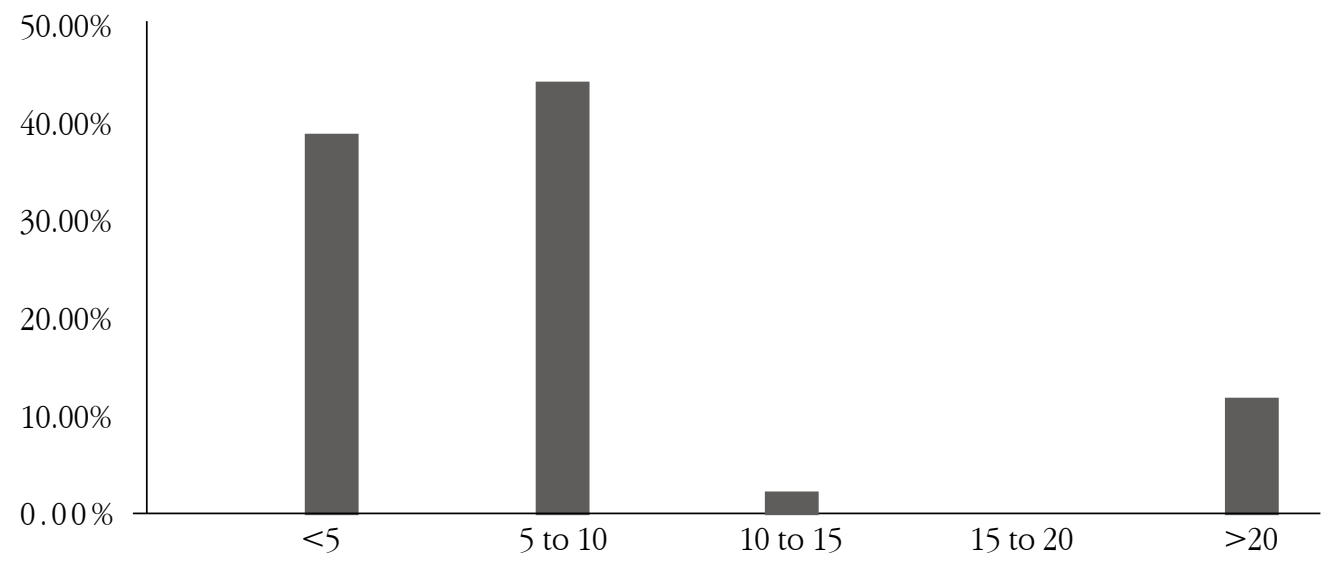

Fig. 4 People's response in the number of Dolphin in the Koshi River 


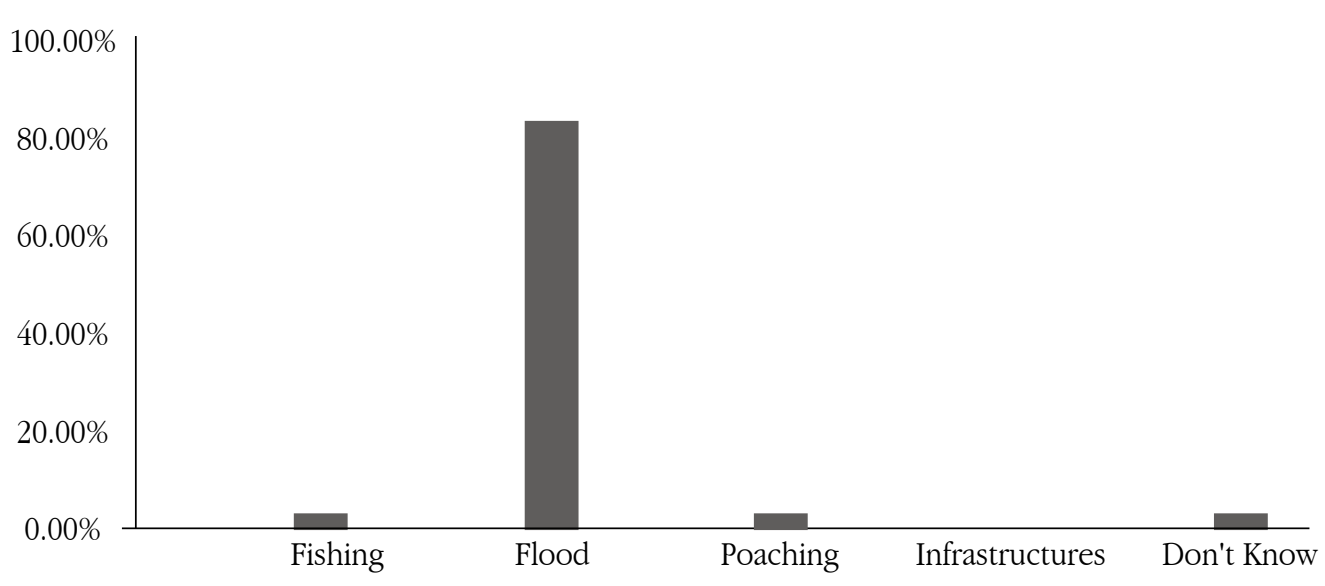

Fig. 5 People's response on factors affecting Dolphin population in the Koshi River

\section{Presence of agencies in Koshi for dolphin conservation} Among the respondents, $41.37 \%$ were unknown about agencies working in the Koshi River for dolphin conservation while $37.93 \%$ were familiar with the agencies. They gave the name of Bird Conservation Nepal (BCN) and KTWR working there for the conservation of dolphin.

\section{Daily fishing of a fisherman}

Out of total, $84.21 \%$ of the fishermen were found fishing 2 $3 \mathrm{~kg}$ of the fishes per day while $15.78 \%$ of the fishermen were found fishing of $5-10 \mathrm{~kg}$ of the fish per day in Koshi River (Prakashpur to Koshi Barrage section) (Fig. 7).

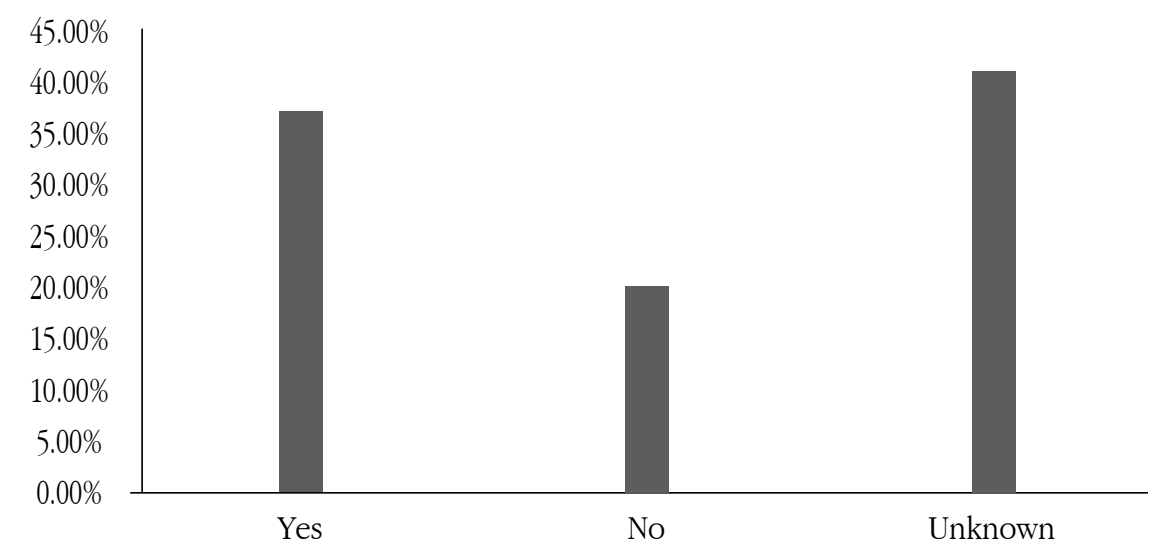

Fig. 6 People's response in the presence of agencies in Koshi River 


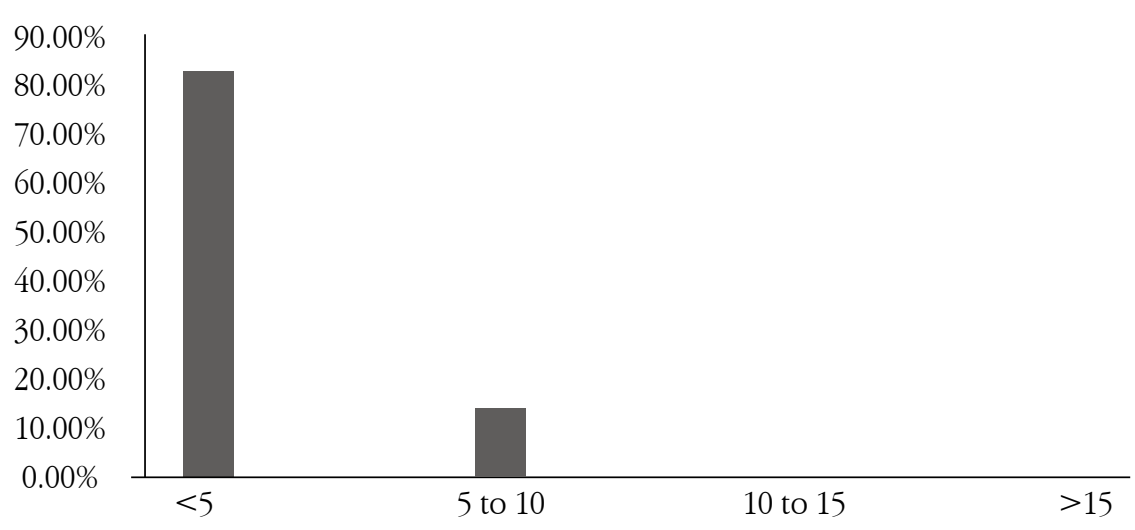

Fig. 7 Per day fishing in the the Koshi River (kg)

\section{Spatial observation of dolphin seen by respondents}

Most of the respondents said the dolphins were commonly sighted near the Coffer Dam constructed for the maintenance of the damaged Koshi Dam by flood in 18 August 2008 at Madhuban, ward No. 9, (26 38' 503”N, and 87 01' 723”E) and near Koshi Barrage. All the respondents said that they had recently seen dolphins in these areas. Among the respondents, $65.51 \%$ reported that dolphin surfacing was observed near Coffer Dam, 17.24\% reported that dolphin surfacing near Koshi Barrage, while 17.24\% reported that they saw dolphins a year ago while the Koshi Dam was damaged by flood at West Kushaha Sunsari near KTWR office and during the rescue of the dolphins by army personals (Fig. 8).

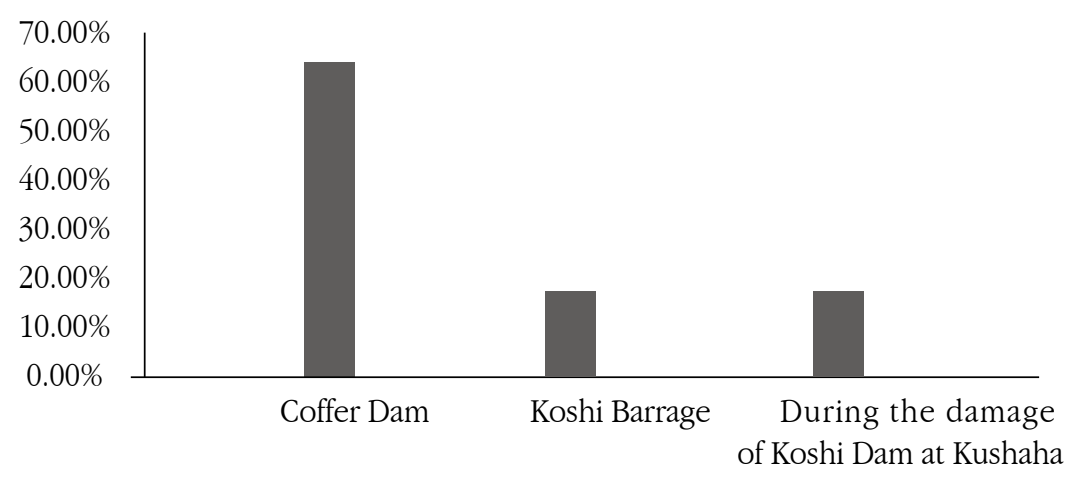

Fig. 8 Spatial observation of Dolphin by respondents

\section{Discussion}

In a survey carried out in the river section between Koshi Barrage and Barahachetra, a total population of 8 dolphins upstream of the Koshi Barrage was found (Shrestha, 1989). Smith et al. (1996) surveyed the area between the confluence of the Arun and Sun-Koshi Rivers, and the Koshi Barrrage during March-April and found only 3 dolphins. Chaudhary (2007) carried a survey between Chatara and Koshi Barrage during October 2006 and January 2007 and found no dolphins upstream of the Koshi Barrage. But present study has shown the presence of the two river dolphins at ward No. 9 of Madhuban VDC of Sunsari District. Shrestha (2010) found a total of 12 river dolphins at Kushaha-Koshi Barrage section during a survey. Out of them seven were at Kushaha and five at Koshi Barrage. The study revealed one more dolphin at Koshi Barrage and three more dolphins at Kushaha and this may be due to the sampling techniques because all 
the sampling techniques may not reveal the same results. Four individuals of river dolphins were found below Koshi Barrage at eastern part. This study has shown that status of dolphin has been found at the areas of high human disturbances. These areas are suitable habitat for the dolphin as these are deep water sites where the river water is moving with fast current. The reason for human activities in the Koshi Barrage is that it is a better and easily accessible holy place for bathing after the completion of worship and most of the religious activities according to the Hindu culture. High human disturbance at Coffer Dam is due to maintenance of damaged Koshi Dam. But the site is suitable habitat for the dolphin where there are confluences of river branches making availability of more prey of dolphin. Also these both site have security guard posts. The habitat loss of the dolphins intensive fishing, and large river works construction for the various infrastructures are the major threats to the decrease of the dolphin population.

The study shows that all the physicochemical parameters studies are in within the range of CBS (2008) signifying that there is no extreme water pollution in the Koshi River in dry season. The parameters are suitable enough to support the aquatic flora and fauna including dolphin. Extreme fluctuation of these parameters in the water causes unusual situation to support the aquatic habitats and hence extreme conditions of these parameters are detrimental for aquatic lives including dolphin in rainy season. The extreme conditions are also from the results of human beings that support to degrade the water quality of dolphin habitats that becomes threat to its survival. Various anthropogenic activities like extreme pesticide use in nearby agricultural land in Koshi, industrial sewage to Koshi, sand and gravel mining from the river etc helps to fluctuate the water quality and the survival of aquatic flora and fauna becomes uncertain.

The respondents reported that there is change in the population of the dolphin in the Koshi River. Of the total respondents, $51.71 \%$ reported the decrease in number and $27.58 \%$ reported the increase in the number of dolphins. The logic to say increase in the number of dolphin in the Koshi River is that the Koshi flood damaged the dam and changed the route and joined to the Ganges. This created direct route for dolphins to migrate upstream and thus the number increased. But the logic to say decrease in the number is that, the high flood that damaged of the dam destroyed the habitats of the dolphin and also the number of the dolphin decreased as they directly flow to the Ganges. They also revealed that the construction of irrigation canal at Chatara, establishment of Ferry above Chatara and Koshi Barrage destroyed the dolphin habitat. Fishing and poaching are also the causes for the threat of dolphin (Chaudhary, 2007). Cases of deliberate killing of dolphin were reported in Indian territory during interviews with the local fishermen. By-catch in the Koshi River of the Nepalese territory is occasional.

The raft survey carried out has reveled total of six river dolphins from Prakashpur to Koshi Barrage section. But $44.82 \%$ of the respondents reported the highest, 5-10 individuals, dolphins in whole Koshi River which seems reliable to the raft survey. Since, the study area has a lot of suitable habitats for dolphins; the Dolphins might have concentrated in this section rather than their migration to the tributaries of the Koshi River.

The burst of the dam of Koshi due to the high flood has damaged the habitats of river dolphin in the Koshi. The remnant population is also found very much affected by the construction activities for the maintenance of the dam through water pollution and noise. Irrigation by damming a long and low gated barrage and the construction of a number of embankments have caused major changes in the Koshi River water flow pattern, sediment load and water quality (Rajbanshi, 2002). Such changes can severely affect the Koshi river dolphins. Embankments of the size of $40 \mathrm{~km}$ and $12 \mathrm{~km}$ along the eastern and western river banks in the Koshi River for extensive flood control have restricted to the floodplain habitats that are critical for reproduction and growth of river fishes. This can result in reduced fish production and thus can affect the dolphins (Chaudhary, 2007). The Koshi High Dam that is planned to be built to a height of $269 \mathrm{~m}-335 \mathrm{~m}$ and the construction of a $165 \mathrm{~km}$ long water way from Chatara can imply a series of upheavals for the environment of the Koshi River (Environmental News Service, 2004). Pollution and river poisoning is another major threat for the decline of the dolphin population. Various synthetic chemicals like fertilizers and pesticides are misused by people of the Koshi River area for poisoning of river and also use various toxic plants extracts as fish poison for mass fishing in the Koshi River as reported by park staffs. Yadav (2002) reported that fishermen were usingAgave americana, Sapium insinge, Dioscorea sp, Euphorbia vovelanavo for fishing in the Koshi River. Fish poisoning can directly and indirectly harm the Koshi river dolphins. Similarly use of current in some places of the Koshi River is also reported by park staffs and local people.

This study finds only fiew organizations working for the conservation and management of dolphins and dolphin habitats in the Koshi River. In this area, BCN is working for the conservation management of birds and their prey fishes. This approach has indirectly helping to conserve the dolphin. KTWR seems passive enough to conserve Gangetic dolphin in this area. 
KTWR has given license to six groups of the fisherman as Wetland Users Groups (Simsar Upabbokta Samuba). This group contains 15-20 members of fisherman. An average of per day fishing of a fisherman is $2.5 \mathrm{~kg}$. So, an average of about $44 \mathrm{~kg}$ per day per group and an average of about 396 $\mathrm{kg}$ per day of the total group is legal fishing in KTWR and also there is high illegal fishing. This has impacted the decrease in the fish population of dolphin that make up the major prey diet for dolphin.

\section{Conclusion}

The Ganges river dolphin are in threats due to different anthropogenic pressures. There were only two dolphins found in the upper section of the Koshi Barrage. During the survey carried out below the Koshi Barrage, only 4 dolphins were sighted. People reveled that there used to be $10-15$ of dolphins in this section but because of changed route by the Koshi River there was a low water level to support the dolphin habitat, so they might have migrated to the Ganges in India. Even though a rare sighting of the species has been reported by locals in irrigation canals and small tributaries of the Koshi River during Monsoon, their distribution is limited from Koshi Barrage to Chatara.

The present study shows that all the physicochemical parameters studies are in within the range for aquatic lives (CBS, 2008) signifying that there is no extreme water pollution in the Koshi River. The parameters are suitable enough to support the aquatic flora and fauna including dolphin. Various human activities like fishing, washing, transporting forest products, establishment of the ferry, construction of irrigation canals, high dams provide threats to the dolphin although questionnaire survey revealed flood, temporal response, to be the major threat. It is also concluded that, the flood is major limiting factor that not only declines the dolphin population but also greatly damages and reduces the suitable dolphin habitats in the Koshi River. Low level of awareness among people, accidental killing and catch and blocked migratory route of the dolphins are also found as key issues. These effects may be considered deleterious to dolphin populations. Very few GOs, NGO, and INGOs, and local organizations are working for the conservation of the endangered river dolphin.

\section{Acknowledgements}

The authors are thankful to WWF-Nepal for partial funding. The authors are grateful to Central Department of Environmental Science, Tribhuvan University, Kathmandu, Nepal for laboratory facility. We sincerely acknowledge the contribution of Mr. Bizanat Khanal, Mr. Om Uprety, Mr. Diwas Dahal, Mr. Arjun Thapa and Mr. Sanjan Thapa and all the colleagues who contributed directly or indirectly during the course of the research.

\section{References}

American Public Health Association/American Water Works Association/Water Environment Federation (1995). Standard Methods for the Examination of Water and Waste Water (19th Edition). Washington D.C., American Public Association.

CBS (2008). Environment Statistics of Nepal. Government of Nepal, National Planning Commission Secretariat, Central Bureau of Statistics, Kathmandu, Nepal.

Chaudhary, S. (2007). Status of, and Threats to, the Ganges River Dolphin (Platanista gangetica) in the Koshi River, Nepal (Unpublished Master's Dissertation). University of Klagenfurt, Austria.

Environment News Service (2004). High Dam Planned for Nepal's Saptakosi River.

IUCN (1996). 1996 IUCN Red-list of Threatened Animals, Gland, Switzerland, IUCN.

IUCN (2004). 2004 IUCN Red-list of Threatened Species. Gland, Switzerland, IUCN.

Rajbanshi, K.J. (2002). Zoo-geographical distribution and status of cold water fish in Nepal. The Symposium on cold water Fishes of Trans-Himalaya Region. Rome, Food and Agriculture Organisation of United Nations.

Shrestha, T.K. (1986a). Ecology of Gangetic Dolphin Platanista gangetica in the Karnali River in Nepal Himalaya: Geoecological Perspectives. In S.C. Joshi (Ed.), Himalayan Research Group (pp.112-142). National Index.

Shrestha, T.K. (1986b). The Ganges Susu is declining in Nepal. Newsletter of IUCN Cetacean Specialist Group 2,10-11.

Shrestha, T.K. (1989). Biology, Status and Conservation of the Ganges River Dolphin in Nepal. In W.F. Perrin, R.L Brownell, Jr. Z. Kaiya, \& L. Jiankang (Eds.), Occasional papers of IUCN/SSC, No.3. pp. 70-76.

Shrestha, T.K. (2010). Saptakoshi river good habitat for gangetic dolphins. The Rising Nepal, April 21.

Sinha, R.K., Sinha, S.K., Sharma, G., \& Kedia, D.K. (2004). Surfacing and diving behaviour of free ranging Ganges dolphin, Platanista gangetica gangetica. Current Science, 98, 230.

Smith, B., Bhandari, B., \& Sapkota, K. (1996). Aquatic Biodiversity in the Karnali and Narayani River Basins. Kathmandu, IUCN.

Trivedy, R.K., \& Goel, P.K. (1986). Chemical and Biological Methods for Water Pollution Studies (1st Edition). KARAD, Environmental Publication.

Wakid, A. (2005). Status and distribution of endangered Gangetic dolphin (Platanista gangetica gangetica) in the Brahmaputra River within India in 2005. Current Science, 97, 1143.

Yadav, S. (2002). Survey of capture fisheries in the Koshi River Basin. Symposium on cold water Fishes of Trans Himalaya region. Rome, Food and Agriculture Organization of United Nations. 